\title{
PENGATURAN HUKUM PENGELOLAAN PERTAMBANGAN BATUBARA SECARA BERKELANJUTAN DI KOTA SAMARINDA
}

\author{
Siti Kotijah \\ Fakultas Hukum Universitas Mulawarman, fafa_law@yahoo.com
}

\begin{abstract}
Legal arrangements on sustainable management of Coal Mining in Samarinda, have many rules violation in the provisions of the Mineral and Coal Act number 4 of 2009 particularly on Mining Management section. These predicaments caused profound consern due to the importance of natural resources preservation for sustainable development for the next generations. Therefore, to manage the existing natural resources which is coal, a sustainable long term regulation is needed in order to gain maximum benefits from coal management. Then, the benefits not only enjoyed by the present generation but also by the future generations.
\end{abstract}

Key word: Law, management, Coal Mining.

\begin{abstract}
Abstrak
Pengaturan hukum Pengelolaan Pertambangan Batubara Berkelanjutan di Kota Samarinda, banyak yang menyimpangi aturan-aturan yang ada dalam ketentuan dalam UU No. 4 Tahun 2009 tentang Pertambangan Mineral dan Batubara, dalam sistem pengelolaan pertambangan. hal ini amatlah mencemaskan mengingat pentingnya pemeliharaan sumber daya alam tersebut demi pembangunan berkelanjutan masa depan bagi generasi yang akan datang, oleh karena itu dalam mengelola sumber daya alam yang ada yaitu batu bara juga diperlukan adanya suatu regulasi tentang rencana jangka panjang yang berkelanjutan supaya manfaat dari pengelolaan batu bara tersebut tidak hanya dinikmati oleh generasi sekarang melainkan juga dari generasi yang akan datang.
\end{abstract}

Kata Kunci: Hukum, Pengelolaan, Pertambangan batubara.

\section{Pendahuluan}

Konsep dasar hak menguasai negara atas kekayaan sumber daya alam oleh negara termuat dalam Pasal 33 ayat (3) UUD 1945 yang berbunyi: "bumi dan air dan kekayaan alam yang terkandung didalamnya dikuasai oleh negara dan dipergunakan untuk sebesar- besarnya kemakmuran rakyat. Ketentuan pasal 33 ayat (3), dapat diartikan dalam hubungan antara negara dengan bumi, air dan kekayaan alam yang terkandung didalamnya adalah hubungan penguasaan. Artinya bumi, air, dan kekayaan alam yang terkandung didalamnya itu dikuasai oleh 
negara dan dipergunakan untuk sebesarbesarnya kemakmuran rakyat, termasuk dalam hal kekayaan sumber daya alam berupa mineral dan batubara.

Dalam pengelolaaan pertambangan Mineral dan batubara, ini harus terjamin hak warga negara terhadap hak lingkungan yang baik dan sehata, yang diatur di Pasal $28 \mathrm{H}$ ayat (1) Undang-undang Negara Republik Indonesia Tahun 1945 bahwa,"Setiap orang berhak hidup sejahtera lahir dan batin, bertempat tinggal, dan mendapat lingkungan yang baik dan sehat serta berhak memperoleh pelayanan kesehatan." Dasar pengaturan tersebut, maka warga negara untuk lingkungan yang baik dan sehat merupakan salah satu bentuk hak sosial, senada seperti yang dikemukakan Philipus M Hadjon bahwa: hak-hak kodrat dan human right yang dikonversi menjadi hakhak hukum disebut fundamental right.. ${ }^{1}$

Salah satu upaya pemerintah dalam memenuhi hak atas lingkungan yang baik dan sehat dalam pengelolaan pertambangan adalah pembangunan yang berkelanjutan dalam pertambangan yang diintegasikan dalam rangka pembangunan jangka panjang,

${ }^{1}$ Philipus M. Hadjon, Perlindungungan Hukum Bagi Rakyat, Peradapan, 2007, h. 35. Kemudian Siti Sundari Rangkuti, Hukum lingkungan dan Kebijaksanaan Lingkungan Nasional (2005; 275) di Belanda, het recth op een goed echoon miliau diformulasikan dalam bentuk hak asasi sosial, yaitu sebagai kewajiban pengelolaan dari penguasa yang dirumuskan dalam Grondwet. Di Indonesia, perumusan hak atas lingkungan lebih jelas, tetapi penempatannya setingkat lebih rendah, yaitu dalam "piagam hak asasi manusia", undang-undang dan formulasinya berbentuk hak klasik. Prinsip 3 Deklarasi Rio (1992) mengenai" Hak Terhadap Pembangunan" (The Right to Developtment) yang terkait dengan Prinsip 1. jangka menengah, dan jangak pendek. ${ }^{2}$

Pertambangan batubara memiliki peran penting dalam pembangunan dengan menghasilkan bahan-bahan baku untuk industri, penyerapan tenaga kerja, sebagai sumber devisa negara dan meningkatkan pendapatan asli daerah. Usaha pertambangan memperkenalkan teknologi, melatih tenaga terampil, dan memasukkan pola manajemen modern. ${ }^{3}$ Sedangkan pada sisi lain dampak akibat pertambangan batubara berupa kerusakan/pencemaran lingkungan baik air, darat, dan udara, kebisingan, serta konflik sosial

Untuk usaha pertambangan batubara di Kota Samarinda Kalimantan Timur, dalam beberapa tahun terakhir, menghasilkan berbagai dampak buruk terhadap masalah lingkungan, antara lain berupa pembabatan hutan pada kegiatan eksplorasi dan eksploitasi, pengupasan/penggalian tanah, kebisingan mesin-mesin pertambangan, hilang daerah resapan air, pencemaran udara oleh debu-debu mesin pertambangan dan pencemaran air akibat pembuangan limbah/ tailing ke Sungai Mahakam. Dampak buruk lainnya, usaha pertambangan dapat pula memicu terjadinya konflik sosial antar pengusahan pertambangan dengan masyarakat sekitar kawasan pertambangan atau antara sesama masyarakat disekitar tambangaan. Masyarakat sekitar tambangan

${ }^{2}$ Berdasarkan Lampiran Undang-Undang Nomor 17 Tahun 2009 tentang Rencana Pembangunan Jangka Panjang Nasional 2005-2009, telah ditetapkan tahapan dan skala prioritas untuk mencapai sasaran pokok pembangunan jangka panjang nasional. Tahapan dan skala prioritas telah disusun terdiri atas RPJM ke-1 (2005-2009), RPJM ke-2 (2010-2014), RPJM ke-4 (2020-2024).

${ }^{3}$ Email Salim, Ratusan Bangsa Merusak Satu Bumi, Kompas, Jakarta, 2010, h. 43. 
dengan Pemerintah Kota Samarinda, bahkan pertambangan batubara sudah menyebabkan terjadinya korban jiwa lima (6) anak dikawasan sumur bekas tambang. ${ }^{4}$ Hal ini menunjukan pemanfaatan sumber daya alam.

Pengelolaan pertambangan mineral dan batubara di Indonesia di atur dalam ketentuan dalam Undang-undang Nomor 4 Tahun 2009 tentang Pertambangan Mineral dan Batubara. ${ }^{5}$ Pertambangan batubara seperti di sebutkan di atas, selain memberi sisi positif dan sisi negatif. Untuk itu pemanfaatan pengelolaan pertambangan batubara harus dilakukan secara berlanjutan, dalam rangka mewujudkan kesejahteraan bagi warga negara

Pengembangan pengelolaan pertambanganbatubara secaraberkelanjutan, dalam hal ini berbasis lingkungan adalah suatu kebutuhan mutlak. Untuk itu pertambangan batubara harus berjalan beriringan dengan upaya perlindungan dan pengelolaan lingkungan hidup dengan cara mengembangkan pengelolaan pertambangan mineral berbasis lingkungan yang berkelanjutan. Pentinganya pembangunan berlanjutan, dengan menyimbangkan atau

\footnotetext{
${ }^{4}$ Kejadian meninggalnya 5 (lima) korban anak dibekas sumur usaha pertambangan Minerba di Kota Samarinda Kalimantan Timur. Usaha pertambangan batubara yang dekat pemukiman warga, bekas sumur tambang tidak dijaga dan dibiarkan dengan standar opesional yang baik dan rambu-rambu keamanan yang memandai, sehingga anak-anak dibiarkan bebas bermain disumur bekas tambang tersebut, sehingga megakibatkan meninggalnya beberapa anak. Kaltim post, Tahun 2011, tenggelamnya bocah dibekas sumur tambang batubara". Namun sampai sekarang kasus hukum tersebut tidak pernah terselesaikan sampai di meja pengadilan.

${ }^{5}$ Undang-undang Nomor 4 Tahun 2009 tentang Pertambangan Mineral dan Batubara, (LNRI Tahun 2009 Nomor 4 dan TLNRI Nomor 4959);
}

mengharmonisasikan antara pembangunan ekonomi dan daya dukung lingkungan mengacu pada Deklarasi Stockholm 1982, prinsip The Rio Declaration on Environment and Development, 1992, bahwa: ${ }^{6}$ “ Human being are at centre of concerns for sustainable development. They are entitled to a healthy and productive life in harmony with nature.

Dari ketentuan diatas, pengaturan pengelolaan pertambangan batubara, merujuk juga ketentuan aturan hukum internasional, dan hukum nasional. Beranjak dari uraian diatas, maka rumusan masalah dalam penelitian ini adalah Pengaturan Hukum Pengelolaan Pertambangan Batubara Berkelanjutan di Kota Samarinda.

\section{Pengelolaan Pertambangan Batubara}

Pertambangan batubara adalah pertambangan endapan karbo yang terdapat di dalam bumi, termasuk bitumen padat, gambut, dan batuan aspal. Sedangkan Pertambangan Mineral adalah pertambangan kumpulan mineral yang berupa bijih atau batuan, di luar panas bumi, minyak dan gas bumi, serta air tanah. ${ }^{7}$ Proses kegiatan pencarian sampai dengan pemanfaatan batubara dibagi dalam 7 (tujuh) tahapan:

1. Penyilidikan umum;

${ }^{6}$ Konferensi UNCED yang juga dikenal dengan nama Earth Summit menghasilkan : a). Convention on Biological Diversity, b) Convention on Climate Change, c) Agenda 21, d) The Forest Prinsip, dan e). Rio Declaration on Environmenta and Development.

7 Dalam penelitian desertasi ini, ruang lingkup kajian dibatasi hanya pada pertambangan batubara. Hal ini dikarena untuk menghindari kajian yang lebih luas dari pertambangan itu sendiri dan kedua di Kota Samarinda paling banyak ijin kuasa pertambangan pertambangan batubara. 
2. Ekplorasi;

3. Studi Kelayakan;

4. Konstruksi;

5. Eksloitasi/produksi;

6. Penutupan tambang; dan

7. Pasca Tambang

Dalam kegiatan pertambangan batubara ditujuhkan pada kesejahteraan, baik masa sekarang, maupun masa mendatang, yang semua itu harus memenuhi kaidah dalam pertambangan batubara yang baik dan benar, antara lain memperhatikan : a) lingkungan fisik dan kimia, b) lingkungan sosial dan ekonomi masyarakat sekitar, dan c) lingkungan pasca tambang.

\section{Konsep Pembanguan berkelanjutan}

Konsep pembangunan berkelanjutan, dalam rangka menyeimbangkan atau mengharmonisasi antara pembangunan ekonomi, dalam hal ini pertambangan batubara dengan daya dukung lingkungan mengacu kepada prinsip 1 Rio Deklaration on Environmental and Development, 1992, bahwa: "Human beings are at the centre of concerns for sustainable development. They are entitled to a healthy and productive life in harmonay with nature".

Konsep pembangunan berkelanjutan sebagai pola pembangunan berwawasan lingkungan (ecodevelopmenty) dengan prinsip-prinsipnya mengaju pada Deklarasi Stockholm 1972. Dari 5 (lima) dokumen

\footnotetext{
${ }^{8}$ Konferensi UNCED yang juga dikenal nama Earth Summit menghasilkan: a). Conveention on Biological Diversity, b). Convetion on Climate Change, c). Agenda 21, d).Forest Principles, and e). Rio Deklaration on Environmental and Developtment.
}

yan dihasilkan pada UNCED, terdapat 5 (lima) prinsip utama dari pembangunan berkelanjutan dan berwawasan lingkungan yaitu:

1. Keadilanantargenerasi(intergenerational equity);

2. Keadilandaamsatugenerasi(intragenerational equity);

3. Prinsip pencegahan dini (precautionary principle);

4. Perlindungan keanekaragaman hayati (conservation of biological diversity); dan

5. Internalisasi biaya lingkungan dan mekanisme insentif (internalisation of environment cost and incentive mechanism). ${ }^{9}$

Kekhawatiran terhadap dampak dari usaha pertambangan terhadap lingkungan, dalam hal ini perdagangan bebas terhadap lingkungan menjadi isu Konperensi Tingkat Menteri Lingkungan dan Perdagangan di Jenewa 1994 dan UNCTAD. Menurut Sarwono Kusumatmadja, telah memberikan peringatan kepada masyarakat Indonesia, bahwa semakin tinggi voume ekonomi akan semakin tinggi resiko terhadap perusakan lingkungan dan penggunaan sumber daya alam. ${ }^{10}$ Dampak perdagangan bebas terhadap lingkungan ada umumnya menyangkut 2 (dua ) isu yaitu: pertama Relokasi industri dari negara maju kenegara berkembang (industrial flight); dan kedua Pandangan bahwa investasi lingkungan tidak mendukung persaingan pasar dalam

\footnotetext{
9 Ibid.

10 Republika, 14 Maret 1995.
} 
era perdagangan bebas (environmental investment us reducing cost to increase competitiveness).

Pertambangan dilakukan berasaskan berkelanjutan dan berwawasan lingkungan adalah asas yang secara terencana mengintergasikan dimensi ekonomi, lingkungan dan sosial budaya dalam keseluruhanusahapertambanganmineraldan batubara untuk mewujudkan kesejahteraan masa kini dan masa mendatang. Hal ini sesuai dengan perlindungan lingkungan hidup dalam Energy Charter Treaty (ECT), Pasal 19 Ayat (1), menyebutkan mengatur kewajiban lingkungan secara umum selain 11 area khusus yang dilakukan oleh anggota untuk mencapai tujuan tersebut:

“In Pursuit of sustainable development and taking into account its obligations under those internasional agreement concerning the environment to which it is party, each contracting party shall strive to minimize in an economically effecientmannerharmfulenvironmental impacts $^{11}$ occurring either within or outside its area from all operations within the energy cycle in its area, taking paper account of safety. In doing so each contracting party shall act in a cost-effective manner. In its policies and actions each contracting party shall strive to take precautionary measures to prevent or minimize environmental

${ }^{11}$ Environmental impact berarti setiap pengaruh yang disebabkan oleh aktivitas terhadap lingkungan, termasuk kesehatan dan keselamatan manusia, flora, fauna, tanah, udara, air, iklim, monument sejarah atau struktur fisik lainnya atau intraksi dari faktor keseluruhan, juga termasuk pengaruh terhadap kondisi warisan budaya atau sosioekonomi yang diakibatkan dari perubahan faktor-faktor tersebut, (Pasal 19 Ayat (3) b ECT. degradation. The contarcing parties agree that the polluter in the areas of contracting parties, should, in principle, bear the cost of pollution, including transboundary pollution, with due regard to the public interest and without distorting investment in the energy cycle or internasional trade.

Pembangunan usaha pertambangan berlanjutan memperlukan komitmen baik dari pemerintah pusat maupun pemerintah daerah. Komitmen ini disusun dilaksanakan secara konsisten oleh para pemangku kepentingan (stakeholder) sebagai langkah awal meletakkan kerangka dasar pembangunan usaha pertambangan yang terarah tanpa merusak lingkungan sekitar.

Prinsip-prinsip pembangunan berkelanjutan memperlukan implementasi dalam bentuk peraturan perundangundangan dan kebijaksanaan pemerintah, sebagaimana dijelaskan oleh Siti Sundari Rangkuti, bahwa: ${ }^{12}$

“Pembangunan berlanjutan merupakan kemauan politik untuk membangun tanpa merusak yang digariskan dalam kebijaksanaan lingkungan dan memperlukan perangkat hukum dalam bentuk peraturan perundangundangan lingkungan. Penggunaan hukum sebagai sarana berdasarkan berdasarkan beberapa kelebihan, yaitu bersifat rasional integratif, memiliki legitimasi dan sanksi serta didukung oleh tersedianya mekanisme

${ }^{12}$ Siti Sundari Rangkuti, Hukum Lingkungan dan Kebijaksaan Lingkungan Nasional, Edisi Ketiga, Airlangga University Press, Surabaya, 2005, h. 384. 
pelaksanaan. Dengan demikian, pemecahan masalah lingkungan tidak berlandaskan teori semata, tetapi didukung dengan kemauan politik serta penegakan perangkat hukumnya."

Pengelolaan pertambagan batubara berlandasarkan pada prinsip pembanguna berkelanjutan. Manusia adalah sebagain dari ekosistem, manusia adalah pengelola pula sistem tersebut. Kerusakan lingkungan adalah pengaruh sampingan dari tindakan manusia untuk mencapai suatu tujuan yang mempunyai konsekuasi terhadap lingkungan. Pencemaran lingkungan adalah akibat dari ambiguitas tindakan manusia. ${ }^{13}$ Hal ini mendasari sikap dan pandangan manusia terhadap alam semesta yang dianggapnya sebagai lawan, yang harus diusahakan untuk ditunduhkan (suppression) dan akhirnya diperbudak (thraldom) guna memuaskan segala keinginan dan nafsunya, anggapan dan faham inilah merupakan dasar bagi konsep hukum hak milik mutlak( eigendom=propriete) seperti yang dianut dalam sistem hukum Eropa dan Amerika yang diwarisinya dari Hukum Rowani Kuno. Dalam dasar hukum hak milik mutklat ini, manusia sebagia pemiliknya dan berbuta semau-maunya terhadap miliknya asal cara panggunaanya tidak akan menganggu hak orang lain dan keamanan masyarakat. Atas

\footnotetext{
13 Kesadarann akan tugas dan kewajiban ini melepaskan manusia dari anggapan lama, bahwa manusia karena dikarunai oleh Tuhan dalam wujud akal dan budi, dititahkan untuk menguasai dan memerintah lain-lain subsistem dan ekosistem seluruh, sehingga diwenangkan berbuat semau-maunya terhadap lain-lain sub sistem dan ekosistem seluruhnya. Hal manusia berusaha untuk mengetahui dan menyelidiki lain-lain subsitem dan ekosistem seluruhnya guna menguasai segala rahasianya, agar dapat mudah (mengetahui dan) menyelidiki alam semesta.
}

dasar faham tersebut tumbuh dan berakar kesadaran hukum bahwa hak milik tidak dapat diganggu gugat dan suci (proipriete estt inviolable et sacre) yang merupakan salah satu standar dasar hukum yang bercorak individualitas. ${ }^{14}$

\section{Pengaturan Hukum Pengelolaan Pertambangan Batubara Berkelanjutan di Kota Samarinda.}

Kota Samarinda ${ }^{15}$ adalah satu-satunya ibukota provinsi yang menjadi kota tambang. Hampir tiga perempat dari wilayahnya sudah ditetapkan sebagai Wilayah Izin Usaha Tambang (WIUP). Data dari Dinas PertambanganKotaSamarindamenunjukkan ada 68 (enam puluh delapan) perusahaan tambang di Samarinda ${ }^{16}$. Perizinan secara keseluruhan sudah mencapai 63 (enan puluh tiga) izin dikeluarkan oleh Pemerintah Kota Samarinda, satu perusahaan izinnya dari Pemerintah Provinsi Kaltim, dan 4 (empat) perusahaan lainnya dari Kementrian

14 Koesnadi hardjasoemantri, Hukum Tata Lingkungan, edisi keenam, cetakan ketiga belas, Gajah Mada Univerisitu press, yogjakarta, h. 6.

15 Gambaran awal Kota Samarinda, dijadikan awal titik ajak penelitian ini di maksudkan untuk memberi gambaran secara umum, bahwa Kota Samarinda, yang kaya akan sumber daya alam batubara, sudah melampai kapasitas daya dukung lingkungan. dampak lingkungan bagi masyarakat. Hal ini juga dialamai daerah Kabupaten yang lain yang seperti Kabupaten Kutai Kartenagara, Kabupaten Paser, dan lainnya Banyak Izin Usaha Pertambangan (IUP) yang dikeluarkan tidak diimbangi dengan pengawasan. Pengelolaan pertambangan batubara yang ada singkron dengan penataan ruang.

16 Pemerintah Kota Samarinda mengeluarkan 68 IUP, sejak otonomi daerah diterapkan, dengan dikeluarkan Undang-undang Nomor 22 Tahun 1999 jo Undang-undang Nomor 32 Tahun 2004 tentang Pemerintah Daerah. Pemerintah daerah diberi kewenangan untuk mengeluarkan izin usaha pertambangan. Banyak IUP yang dikeluarkan oleh pemerintah kota, mengabaikan fungsi laingan seperti :penataan ruang, hutan, sumber daya air, perumahan. Pada akhirnya IUP itu emberi tekanan berat bagi daya dukung dan kualitas lingkungan yang ada di Kota Samarinda. 
ESDM. ${ }^{17}$ Untuk itu dijelaskan dalam peta sebagai berikut:

Berikut Peta Kalimantan Timur dan Samarinda.

Tabel 1 : Peta Kalimantan Timur

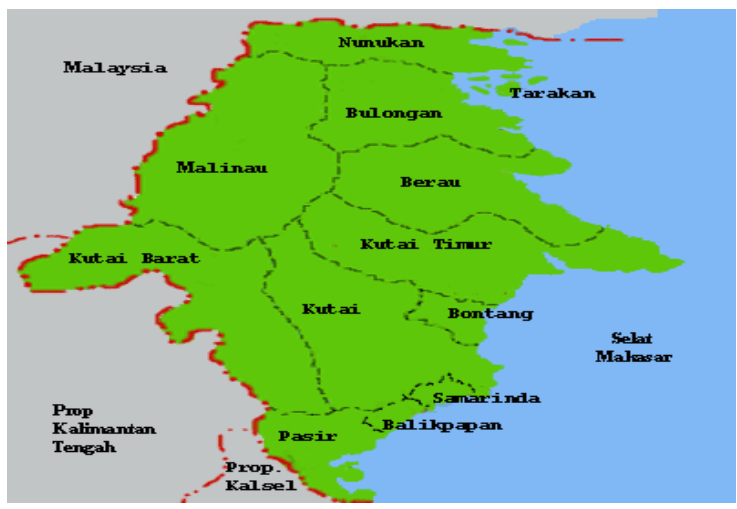

Sumber http://www.kaltimprov.go.id Tahun 2013

Tabel 2 . Peta Kota Samarinda

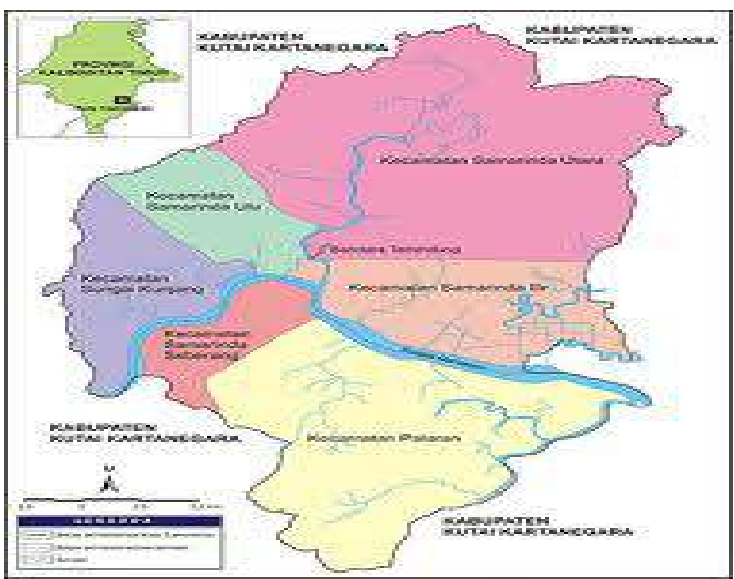

Sumber http://www.kaltimprov.go.id Tahun 2013

${ }^{17}$ http://www.menlh.go.id/penerapan-sangsiadministrasi-paksaan-pemerintah-terhadap-perusahaanpertambangan-di-kota-samarinda, diakses tanggal $15 \mathrm{Juli}$ Tahun 2013.
Tabel 3 . Peta Wilayah Kuasa Pertambangan Batubara di Kota Samarinda

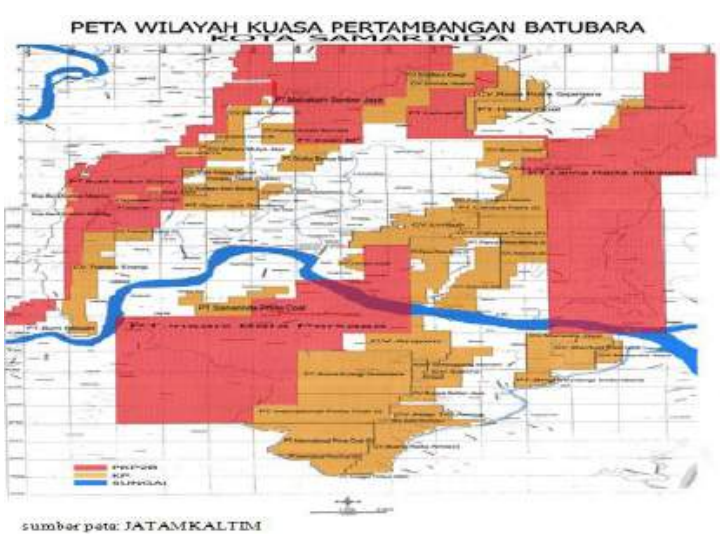

Sumber: Jaringan Tambang Kalimantan Timur, Tahun 2011

Tabel 4 . Peta Izin Wilayah Kuasa

Pertambangan Batubara di Kota Samarinda

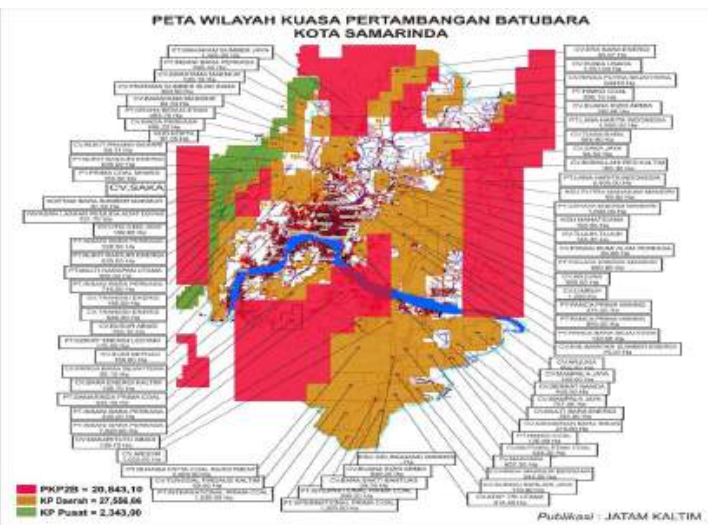

Sumber. Jaringan Tambang Kalimantan Timur, Tahun 2011

Salah satu masalah yang terjadi terkait dengan pertambangan batubara di Kota Samarinda adalah masalah lingkungan. Pembangunan sektor pertambangan batubara di Kota Samarinda, dari peta di atas, dapat interprestasikan bahwa Kota Samarinda sudah melampaui batas daya dukung dan daya tampung lingkungan yang ada. Bagaimana suatu daerah Ibu Kota Propinsi Kalimantan Timur. Dalam pengelolaan pertambangan batubara di 
Kota Samarinda, mengakibatkan beberapa pencemaran lingkungan dan sudah beberapa mendapat sanksi adminitrasi. ${ }^{18}$

PT. Nuansa Coal Invesment telah mendapatkan sanksi administratif berupa teguran tertulis dari Walikota Samarinda Nomor : 660/039/BLH-I/KS/I/2012 tanggal 25 Januari 2012. Dalam kasus pencemaran lingkungan disekitar warga. Settling pond belum memadai, sehingga pengelolaan limbah mencemari sumur warga. Upaya yang telah dilakukan per 25 Januari 2013 telah melakukan pengelolaan lingkungan sesuai dokumen RKL dan RPL, melakukan reklamasi lahan pasca tambang dan dilanjutkan dengan revegetasi, memiliki 3 kolam pengelolaan air limbah (settling pond) dan telah dilengkapi dengan izin pembuangan air limbah, memiliki izin Penyimpanan Sementara Limbah B3, telah rutin melakukan pengujian air limbah per bulan dan melakukan swapantau kadar parameter $\mathrm{pH}$ dan debit harian dan telah rutin melakukan pengukuran kualitas udara.

PT. Insani Bara Perkasa (PT. IBP), sebelummelakukanpencemaranlingkungan, pengelolaan air limbah yang dihasilkan mengalir tempat warga. Sehingga air tidak bisa dipakai untuk kebutuhan seharihari. Berstatus belum taat karena sejak mendapatkan teguran tertulis melalui Surat Walikota Samarinda No. 660/151/BLH-I/ KS/I/2013, tanggal 28 Januari 2013, dengan kewajiban yang harus segera dilakukan adalah menyampaikan laporan pelaksanaan RKL-RPL secara rutin dan tepat waktu, lebih maksimal melakukan pengelolaan

\footnotetext{
18 Ibid
}

air limbah yang dihasilkan sebelum dibuang ke media lingkungan, melakukan swapantau parameter $\mathrm{pH}$ dan debit harian secara rutin. Dari hasil pemantauan per 25 Januari 2013 PT. IBP belum menyampaikan laporan pelaksanaan RKL-RPL triwulan IV Tahun 2012, pengelolaan air limbah belum maksimal, namun sudah memiliki Izin Penyimpanan Sementara Limbah B3.

CV. Bara Energi Kaltim (CV. BEK), tidak melakukan pasca reklamasi pada bekas galian batubara. dikenai sanksi administratif pencabutan izin usaha oleh Pemerintah Kota Samarinda karena setelah mendapat teguran tertulis melalui Surat Walikota Samarinda No. 660/1126/BLH-I/ KS/IX/2012, tertanggal 25 September 2012, yang bersangkutan tidak melakukan pengelolaan lingkungan sesuai dengan dokumen RKL-RPL, pengelolaan air limbah tidak maksimal walaupun telah memiliki izin pembuangan air limbah namun belum rutin melakukan pengujian kualitas air limbah per bulan, pemantauan $\mathrm{pH}$ dan debit harian. Kondisi setling pond tidak terawat dan tidak melakukan pengujian kualitas udara ambient secara rutin per semester. CV.BEK juga diperintahkan untuk melakukan pemulihan lingkungan (reklamasi pasca tambang). ${ }^{19}$

Setiap tahun di Kota Samarinda, korban nyawa berjatuhan di bekas lubang galian pertambangan batubara yang tidak dilakukan upaya pascatambang atau upaya reklamasi bekas tambang di Kota Samarinda, pada tahun 2011 hingga 2012

${ }_{19}$ http://www.menlh.go.id/penerapan-sangsiadministrasi-paksaan-pemerintah-terhadap-perusahaanpertambangan-di-kota-samarinda, diakses tanggal 15 Juli Tahun 2013. 
sudah 6 (enam) orang anak tewas tenggelam di lubang raksasa yang kini menyerupai danau tersebut. Selama ini proses penegakan hukum tidak jelas statusnya, baik terkait wewenang, pengaturan, dan prosedur dalam penegakanya terkait kasus tersebut. ${ }^{20}$

Pembangunan pada sektor pertambangan batubara pada dasarnya merupakan bagian dari pembangunan sumber daya alam dengan memperhatikan lingkungan yang sekitarnya secara keseluruhan, yang merupakan komponen penting sistem penyangga kehidupan global, regional dan nasional. Ketentuan mengenai pentingnya perlindungan dan kelestarian lingkungan untuk membangun sumber daya alam dalam memberikan nilai tambah nyata kepada pertumbuhan ekonomi dan pembangunan daerah secara berkelanjutan.

Pengelolaan pertambangan mengacu pada Undang-undang Nomor 4 Tahun 2004 tentang UU Minerba, dan peraturan pelaksanaanya, antara laian: Peraturan Pemerintah Nomor 23 Tahun 2010 to Peraturan Pemerintah Nomor 24 Tahun 2012 tentang Pelaksana Kegiatan Usahan Pertambangan Mineral dan Batubara, Peraturan Pemerintah Nomor 22 Tahun 2010 tentang Wilayah Pertambangan dan Peraturan Pemerintah Nomor 68 tentang Reklamasi dan Pasca Tambang. Untuk pengawasan menunjuk pada Peraturan Pemerintah Nomor 55 Tahun 2010

${ }^{20}$ Dalam kasus meninggalnya 6 bocah dibekas lubang pertambangan batubara, penegak hukum dalam suatu dilema terhadap pasal kelalihan yang dituduhkan kepada pelaku, yang terdiri dari penguasa tambang yang tidak memberi tanda dalam bekas sumur pertambangan batubara, Pemerintah Daerah Kota Samarinda, yakni Badan Lingkungan Hidup Kota Samarinda, dan orangtuan yang kurang menjaga anaknya. tentang Pembinaan dan Pengawasan Penyelenggaran Pengelolaan Pertambangan Mineral dan Batubara. Sedangkan Untuk penyelenggaran usaha pertambangan di daerah menunjuk pada Peraturan Menteri dan Sumber Daya Mineral Nomor 02 Tahun 2013 tentang Pengawasan Terhadap Penyelenggaran Pengelolaan pertambangan Yang di Lakukan Pemerintah Propinsi dan Pemerintah Kabupaten/Kota.

Dari perspektif hukum lingkungan dalam rangka pengelolaan pertambangan batubara. Pengelolaan lingkungan dilakuan secara terpadu ("Integrated environmental management approach") penelitian dan pengkajian komprehensif mengenai pengendalian kerusakan lingkungan akibat pertambangan batubara di Indonesia. Pangkal tolak pada penuangan langkahlangkah dan upaya pengendalian kerusakan lingkungan dalam pengelolaan lingkungan hidup dalam rangkaian pengaturan hukum ("regulatory chain") yang digambarkan pada skema .

Skema 1. Pengaturan Hukum (Regulatory Chain)

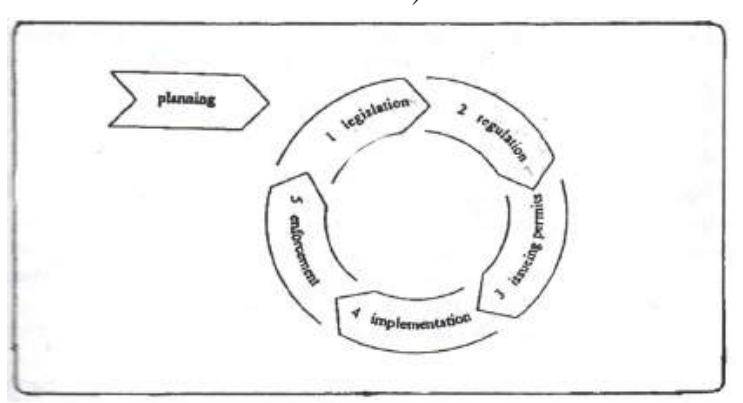

Sumber: Rene Seerden \& Michiel Heldeweg, "Public Environmental Law in the Netherlands", dalam: G.H. Addink, Penataran Environmental Law and Sustainable Development: Literature, Fakultas Hukum Universitas Airlangga, 
Surabaya, 1999, h. 35 dan G.H. Addink,

Environmental Law in a Comparative

Perspective: National, European

and International Law, Institute of

Constitutional and Administrative Law, Utrecht University, Utrecht, 2002, h. 61. Ibid, h.9.

Pengaturan (hukum) pengelolaan lingkungan merupakan integrasi dari keseluruhan pentahapan yang terdiri atas: "legislations", regulations" (setting standards), "issueing permits" (handing out permits), implementation" (implementing regulations and permits) dan "enforcement" yang berawal dari (environmental policy) "planning". Perencanaan adalah bagian penting fungsi manajemen (lingkungan) selain: "organizing, directing, motivating, dan controlling”

Pertambangan batubara adalah pertambangan endapan karbo yang terdapat di dalam bumi, termasuk bitumen padat, gambut, dan batuan aspal. Sedangkan Pertambangan Mineral adalah pertambangan kumpulan mineral yang berupa bijih atau batuan, di luar panas bumi, minyak dan gas bumi, serta air tanah. ${ }^{21}$ Proses kegiatan pencarian sampai dengan pemanfaatan batubara dibagi dalam 7 (tujuh) tahapan:

1. Penyilidikan umum;

2. Ekplorasi;

3. Studi Kelayakan;

4. Konstruksi;

${ }^{21}$ Dalam penelitian desertasi ini, ruang lingkup kajian dibatasi hanya pada pertambangan batubara. Hal ini dikarena untuk menghindari kajian yang lebih luas dari pertambangan itu sendiri dan kedua di Kota Samarinda paling banyak ijin kuasa pertambangan pertambangan batubara.
5. Eksloitasi/produksi;

6. Penutupan tambang; dan

7. Pasca Tambang. ${ }^{22}$

Penyidikan umum adalah tahapan kegiatan pertambangan untuk mengetahui kondisi geologi regional dan indikasi adanya mineralisasi. Penyelidikan umum merupakan tahapan awal untuk mengetahui adanya bahan galian batubara suatu daerah tertentu. Eksplorasi adalah tahapan kegiatan usaha pertambangan untuk memperoleh informasi secara terperinci dan teliti tentang lokasi, bentuk, dimensi, sebaran, kualitas dan sumber daya terukur dari bahan galian, serta informasi mengenai lingkungan sosial dan lingkungan hidup. Dalam penyidikan umum dan ekplorasi dapat dilakukan pada tahap kegiatan ini antara lain: ${ }^{23}$

a. Melaksanakan kegiatan sesuai dengan tahapan dan metode yang benar;

b. Memanfaatkan seoptimal mungkin informasi yang telah tersedia;

c. Mengoptimalkan pengambilan dan penggunaan data lapangann untuk keperluan eksplorasi, maupun persiapan pertambangan (geotkenik, geohidrologi dan informasi air asam tambang);

d. Perhitungan nilai cadangan bahan galian dengan memperhatikan seluruh nilai mineral dan ikutan yang mugkin juga akan tertambang.

${ }^{22}$ Pasal 1 Angka 5 Undang-undang Nomor 4 Tahun 2009 tentang Pertambangan Mineral dan Batubara.

${ }^{23}$ Suyattono dkk, Good Mining Practice; Konsep tentang Pengelolaan Pertambangan yang Baik dan Benar, Studi Nusa, Jakarta, 2003, h. 8. 
Studi kelayakan adalah tahapan kegiatan usaha pertambangan untuk memperoleh informasi secara rinci seluruh aspek yang berkiatan untuk menetukan kelayakan ekonomis dan teknis usaha pertambangan, termasuk analisis mengenai dampak lingkungan serta perencanaan pascatambang. Tahapan ini untuk memperhitungkan nilai-nilai ekonominya dengan mempertimpakan aspek-aspek teknis pertambangan lingkungan, k3, nilai tambah, konservasi bahan galian. Untuk aspek pengembangan wilayah dan masyarakat serta perencanaan awal penutupan pasca tambang. Intinya studi untuk menyakinkan bahwa usaha pertambangan batubara akan layak buat investasi.

Kontruksi adalah kegiatan usaha pertambangan untuk melakukan pembangunan seluruh fasilitas operasi produksi, termasuk pengendalian dampak lingkungan. dalam tahapan ini kegiatan meliputi penyedian/penyiapan sarana dan prasarana dalam permulaan pertambangan batubara. Hahapan yang dapat dilakukan adalah: ${ }^{24}$

a. Pembebasan lahan;

b. Kontruksi jalan tambang, pelabuhan, kantor, gedung, bengkel, base camp, areal pengelolaan, stocyard, initial dumping area, saluran irigasi, settling pond, dan pengupasan lapisan penutup;

c. Pengadaan dan peamsangan peralatan komunikasi, penambangan, pengelolaaan, pengangkutan, lingkungan dan $\mathrm{K} 3$; dan d. Pengadaan tenaga kerja, baik untuk kegiatan kontruksi maupun untuk kegiatan produksi nantinya.

Eksloitasi/produks dalam hal ini tahapan untuk mulai operasi terhadap bahan batubara. untuk operasi produk yang dilakukan untuk tahapan kegiaatn usaha pertambangan yang meliputi kontruksi, penambangan, pengelolaan, pemurnian, dan termasuk pengangkutan dan penjualan, serta sarana pengendalian dampak lingkungan sesuai dengan hasil studi kelayakan. Terakhir tahapan penutupan tambang; dan pasca tambang. Kegiatan pascatambang atau pascatambang, adalah kegiatan terencana, sistematis, dan berlanjut setelah akhir sebagian atau seluruh kegiatan usaha pertambangan untuk memulihkan fungsi lingkungan alam dan fungsi sosial menurut kondisi lokal diseluruh wilayah penambangan. Sedangkan reklamasi adalah kegiatan yang dilakukan sepanjang tahapan usaha pertambangan untuk menata, memulihkan dan memperbaiki kualitas lingkungan dan ekosistem agar dapat berfungsi sesuai dengan peruntukannya.

Dari tahapan pengelolaan pertambangan, pengaturan hukum yang sering dilakukan pelanggaran di Kota Samarinda, dalam hal ini studi kelayakan, dimana seharus pertambangan tidak dilakukan di areal hutan, lahan pertanian, areal sumber air. Untuk pengawasan dari pemerintah penting sejak tahapan awal usaha pertambangan batubara.

\footnotetext{
${ }^{24}$ Ibid, h. 9.
} 


\section{Kesimpulan}

Pengaturan Hukum Pengelolaan Pertambangan Batubara Berkelanjutan di Kota Samarinda banyak menyimpang sejak awal usaha pertambangan batubara, salah satunya yang diabaikan adalah studi kelayakan

\section{Daftar Bacaan}

Anand, Ghansham Karakteristik Jabatan Notaris di Indonesia dan Batas Tanggung Gugatnya, Program Doktor Fakultas Hukum Universitas Airlangga Surabaya, 2013.

Basuki, Nur, Penyalahgunaan wewenanng dalam pengelolaan keuangan Daerah yang berimplikasi tindak pidana korupsi, Disertasi, Pasca Sarjana Universitas Airlangga Surabaya. 2006.

Campbell Black, Henry, Black's Law Dictionary, West Publishing, Co.St, Paul Minnessotta, 1990.

Djojodirdjo, M.A. Moegni, Perbuatan Melawan Hukum, Pradnya Paramita, Jakarta, 1982.

Efendi, Aan Penyelesain Sengketa Lingkungan, Mandar Maju, Bandung, 2012.

Friendman, Lawrence M. Law and Society. An Introduction Englewood Cliffs, N.J. Prentice Hall, 1977.

George W, Rock, Mining Enviroment and Development, A Series of Paper Prepared for the United Nations Conference on Trade and Development (UNCTAD), 2005.

Hadjon, , Philipus M. Perlindungungan Hukum Bagi Rakyat, Peradapan, 2000.
Pengantar Hukum Adminitrasi, Gajah Mada Universitas Press, Yogjakarta, Tahun 1994.

Pengantar Hukum Administrasi Indonesia, Gadjah Mada University Press, Yogjakarta, 1993.

H.L.A. Hart, The Concept Of Law, oxford university press, 1961.

Harjasoemantri, Koesnadi, Hukum Tata Lingkungan, Edisi ketujuh, Cetakan Ketujuhbelas, Gajahmada Universitas Press, Yogjakrta, 1999.

Head, John W, Pengantar Umum Hukum Ekonomi, Edisi Bahasa Indonesia dan Inggris, ELIPS, Jakarta, 1997.

Kleden, Ignas Kearah Pembangunan Bekelanjutan di Indonesia, dalam Buku pembangunan berkelanjutan, mencari format politik, Yayasan SPEDS, Gramedia Pustaka Utama Bekerjasama dengan Yayasan SIPES, Jakarta, 1992.

Komisi Dunia Untuk Lingkungan dan Pembangunan (WCED).

Kerap, Sonny, dalam Proceedings of Ninth Internasional Coral Reef Sysmsium, Bali, 23-27 Oktober 2000, Indonesia Institute of Science, Internasional Society for Regal Studies,

Purbopranoto, Kuntjoro diterjemahkan dengan tindakan pemerintah yang berdasarkan fakta, Beberapa Catatan Hukum Tata Pemerintahan dan Pengadilan Administrasi Negara, Alummi Bandung, 1975.

Santoso, Mas Agus, Good Governance dan hukum lingkungan, ICEL, Jakarta, 2001. 
Suyartono, Good Mining Practice: Konsep Tentang Pengelolaan Pertambangan Yang Baik dan Benar, Studi Nusa, Semarang, 2004.

Sundari Rangkuti, Siti Hukum lingkungan dan Kebijaksanaan Lingkungan Nasional, Airlangga Press, Surabaya, 2005.

Siahaan, N.h.T. Hukum Lingkungan, Pancuran Alam, Jakarta, 2006.
Salim, Emil Pembangunan Berkelanjutan, keperluaan penerapannya di Indonesia, dalam buku pembangunan berkelanjutan, mencari format politik, yaysan SPES Gramedia Pusatka Utama berkerjasama dengan yayasan SPES, Jakarta, 1992.

Saleng, Abrar Hukum Pertambangan, UII Press Yogjakarta, 2004.

Sri Djatmiati, Tatiek, Prinsip Izin Usaha Industri Di Indoenesia, Disertasi Pascasarjana Universitas Airlangga, Surabaya, 2004. 
60 Yuridika: Volume 27 No 1, Januari-April 2012 